This paper was eventually published under the same title in Third World Quarterly, Vol. 28 (3), 2007, forthcoming. This is a draft submitted to the journal prior to the proof.

\title{
CHINA'S OIL DIPLOMACY: IS IT A GLOBAL SECURITY THREAT?
}

\author{
Hongyi Harry Lai
}

\begin{abstract}
China is now the world's second largest oil consuming nation. China's external quest for oil has thus generated much attention and is believed by many to destabilize the world order. The article attempts to provide an overview of China's external initiatives for satisfying domestic oil demands and examine the implications of China's oil diplomacy on regional and global political stability. This article suggests that China has taken three steps for satisfying its growing domestic demand for oil-expands overseas oil supplies from the Middle East, diversifies its importing sources by reaching out to Africa, Russia, Central Asia, and Americas, and secures oil transport routes. This article argues that China's oil diplomacy strengthens its ties with oil producing nations and complicates those with oil importing nations. Nevertheless, contrary to pessimistic predictions, China's oil diplomacy has neither upset the U.S. fundamental policies toward Iraq and Iran, nor has it generated armed clashes in the South China Sea. China has largely accommodated the U.S. in these areas and has forged joint efforts in energy exploration with Asian neighbors except for Japan. China's benign oil diplomacy can be explained by the minor role of oil imports in its energy consumption, and importantly China's peaceful-rise strategy.
\end{abstract}




\title{
CHINA'S OIL DIPLOMACY: IS IT A GLOBAL SECURITY THREAT?
}

\author{
Hongyi Harry Lai
}

\section{Introduction: Documenting and Assessing China's Oil Diplomacy}

Oil has long been viewed as a strategic resource for nations. China is now the world's second largest oil consuming nation. Its global efforts to secure oil imports have profound implications for international relations in the Asia-Pacific. China's rising oil demand and its external quest for oil have thus generated much attention. It is believed that as China's overseas oil quest intensifies, the potential for it to clash with other Asian oil consumers and disrupt the U.S. foreign policy and the world order will also increase.

The article attempts to provide an overview of China's external initiatives for satisfying domestic oil demands and then discuss the implications of China's oil diplomacy on regional and global political stability. This article examines measures that China has taken in order to satisfy its growing domestic demand for oil. It argues that China's oil diplomacy strengthens its ties with oil producing nations and complicates those with oil importing nations. Nevertheless, contrary to many pessimistic predictions, China has largely accommodated the U.S. and has forged joint efforts in energy exploration with Asian neighbors except for Japan.

\section{Arguments about the Threat of China's Oil Quest}

In the recent years, China's demands for imported oil have increased rapidly. Many observers, scholars and politicians take note of this development. Some of them have suggested that in order to quench its oil thirst China will resort to all means to extract all available oil and gas resources, thereby destabilizing the regional and even global order.

One of the most sweeping arguments is that China may enter wars over strategic resources including oil, gas and water around the world. Klare boldly predicts that overlapping claims over oil and gas resources in the South China Sea could trigger armed conflict between China and other claimant states. It would also implicate the U.S. since it has committed to defending the Philippines and sea lanes in that area. In addition, conflicting claims in the East China Sea by China and Japan may erupt into naval clashes. ${ }^{1}$ Another analyst declared that "China's willingness to promote cooperative regional solutions to Asia's energy security concerns has been very limited." proclaimed that China's quest for oil may endanger international security and threaten China's peaceful rise. ${ }^{3}$

Moreover, a number of analysts argue that China's efforts to gain overseas oil supplies can undermine the U.S. national security. For example, China's efforts to increase oil imports from the Middle East could undercut the U.S. efforts to stabilize the

The author thanks Shahid Qadir and anonymous reviewers for their comments, John Wong for his suggestion and help with my research, and Elspeth Thomson for her help with data in Tables 1-2.

${ }^{1}$ Michael Klare, Resource Wars: The New Landscape of Global Conflict. New York: Henry Holt and Company, 2001, pp. xi-xii; 109-137.

${ }^{2}$ Mikkal Herberg, “Asia's Energy Insecurity: Cooperation or Conflict?” in Ashley Tellis and Michael Wills, eds. Strategic Asia 2004-05 (Washington, D.C.: The National Bureau of Asian Research, 2004), p. 353.

${ }^{3}$ Chietigj Bajpaee, “China Fuels Energy Cold War,” Asian Times, March 2, 2005. 
region and reform regimes there and could even reduce U.S oil imports. ${ }^{4}$ In July 2005 the U.S. Congress blocked China's state oil giant China National Offshore Oil Corporation's (CNOOC) bid to take over U.S.-based Unocal Corp on the ground that this bid undermined national security. ${ }^{5}$ It is thus necessary to sort out facts from claims over China's quest for energy security.

\section{Need for a Thorough Assessment and My Argument}

There is a small and growing literature on China's oil diplomacy and energy security. It focuses and sheds bright light on the following issues - China's current and projected energy demands and supplies; its energy structure; its efforts to explore domestic sources, expand production, and increase energy efficiency; implications of China's energy demands and imports on global energy markets. ${ }^{6}$ Several studies also discuss China's efforts, especially those by its state oil corporations to expand into overseas oil markets and acquire oil fields abroad. ${ }^{7}$ Several studies also discuss China's moves to secure sea lanes, plan a strategic oil reserve, and build oil stockpiles and refinery, as well as actors in its energy policies until the late 1990s. ${ }^{8}$

While these studies are informative, they also have their limits. First, analyses in most of these studies appeared to be dated. These studies largely based on the data up to the late 1990s. Into the 2000s many significant changes have taken place. The oil price has shut up drastically from an average of $\$ 13$ per barrel from 1950-2002 to over $\$ 50$ in the last two years. China has adopted many new initiatives in its oil quest, including securing its oil transport route. Some of the conclusions in the studies were based on low oil price and appeared to be invalid. Second, we have yet to have a broad overview and a balanced assessment of China's oil diplomacy, which systemically reviews China's ongoing external endeavor and competition over oil, and evaluates predictions on destabilizing effects of China's oil endeavors. Two recent informative studies emphasize either problematic aspects in China's oil diplomacy especially over courting rouge states such as Sudan and Myanmar, or China's increasing tension in the South and East China

\footnotetext{
${ }^{4}$ Gal Luft, "U.S., China Are on Collision Course Over Oil," Los Angeles Times, February 2, 2004.

${ }^{5}$ Peter S. Goodman, "China Tells Congress to Back Off Businesses: Tensions Heightened by Bid to Purchase Unocal," Washington Post, Tuesday, July 5, 2005; A01.

${ }^{6}$ See, for example, Mehmet Ögütcü, "China's Energy Future and Global Implications," in Werner Draguhn and Robert Ash, eds. China's Economic Security (Richmond, Surrey: Curzon: 1999), pp. 84-141; Robert Manning, The Asian Energy Factor (New York: Palgrave, 2000), pp. 85-118; P. Crompton and Y. R. Wu, "Energy Consumption in China," Energy Economics 27 (1), January 2005, 195-298.

${ }^{7}$ See J. Calabrese, "China and the Persian Gulf: Energy and Security," Middle East Journal 52 (3) (Summer 1998), pp. 351-366; G.X. Ji, "China versus Asian Pacific Energy Security," Korean Journal of Defense Analysis 10 (2), Winter 1998; D. Kerr, "The Chinese and Russian Energy Sectors," PostCommunist Economies 11 (3)(September 1999), pp. 337-372; J. P. Dorian, U. T. Abbasovich, M. S. Tonkopy, O. A. Jumabekovich, and D. X. Qiu, "Energy In Central Asia and Northwest China," Energy Policy 27 (5) (May 1999): 281-297.

${ }^{8}$ Erica Downs, China's Quest for Energy Security (Santa Monica, CA: Rand, 2000); Amy Myers Jaffe and Steven Lewis, "Beijing's Oil Diplomacy," Survival 44 (1) (Spring 2002): 115-134; Philip Andrews-Speed, Xuanli Liao and Roland Dannreuther, The Strategic Implications of China's Energy Needs (Oxford and New York: Oxford University Press for IISS, 2002).
} 
Sea over oil resources. ${ }^{9}$ These studies overlook other encouraging developments in recent years.

Addressing these issues, this article first charts China's growing demands for oil imports, then examines its oil diplomacy since the 1990s, and finally assesses its implication on global security. It makes the following argument: In the wake of its growing oil imports since the late 1990s China has intensified its efforts to secure supplies from major oil producing countries and protect its main oil routes. Overall, China has not only avoided clashing with the U.S., but also has initiated oil cooperation with Asian neighbors. The only cautionary cases are China's ties with Japan and Sudan.

\section{China's Growing Oil Demands}

China's rapidly growing economy has driven up its consumption of crude oil, from a low 88 million tons in 1980 to 252 million in 2003 , and to 293 million tons in $2004 .{ }^{10}$ It is now the world's second largest oil consumer, accounting for one third of the increase in 2003. China's oil imports are also keeping pace with its rapid increase in oil demand. In 2004, China imported 123 million tons of crude oil, up by $35 \%$ from $2003 .^{11}$

China was still self-sufficient in oil as late as in 1997. As China's domestic oil production stagnated and consumption soared, its dependence on net imports of oil (imports minus exports) reached $40 \%$ in 2004 (Table 1). As China's auto and aviation markets continue to expand, China's fuel demands and needs for imports will also soar. Currently, one third of the oil is consumed by automobiles in China. This share is projected to grow to $50 \%$ in 2020 as China's government is promoting the auto market as a pillar industry for economic growth. Most of the increase in China's oil demand will only be satisfied through imports. ${ }^{12}$

Hence China has been pro-active in securing growing oil imports in recent years. In November 2003 Chinese President Hu Jintao declared that oil and finance constituted two components of China's national economic security. As oil is becoming an increasingly relevant factor in China's economic growth, it has assumed importance in China's diplomatic endeavors.

\section{China's Oil Diplomacy: Focusing on the Middle East}

In response to growing oil demands, China's first initiative is to increase imports from the largest oil producing countries, starting from the Middle East. Back in 1995, Southeast Asia and the Middle East were the two dominant sources of oil imports for China. By 2000, however, the Middle East's share increased to a whopping 54\%, whereas the share of Southeast Asia that constituted most of the Asia-Pacific in Table 2

\footnotetext{
${ }^{9}$ See David Zweig and Bi Jianhai, "China’s Global Hunt for Energy," Foreign Affairs, September/October 2005, Vol. 84, No. 5: 25-38; Pak K. Lee, “China’s Quest for Oil Security: Oil (Wars) in the Pipeline?”, The Pacific Review, Vol. 18, No. 2, June 2005: 265-301.

${ }^{10}$ Refer to Table 1 and "Energy Demand Growth Rate to Slow Down," China Daily, December 15, 2004.

${ }^{11}$ China Statistical Yearbook 2005, p. 638; "China Imports 120 Million Tons of Crude in 2004 and Energy Constraints Are Outstanding”, posted at http://www.XINHUANET.com on January 25, 2005.

12 "China May Become the Third Largest Auto-Producing Country in the World," Lianhe Zaobao (United Morning Post), February 5, 2005.
} 
free-fell to $15 \%$ (Table 2). Rising oil demand in Southeast has also led to decline in its oil exports.

Growing oil imports from the Middle East since the mid 1990s can be partly attributed to China's active oil diplomacy targeting at large oil producers. As late as 1995, China's oil imports from the Middle East primarily relied on smaller oil producers, such as Oman and Yeman. By 2003 large producers Saudi Arabia and Iran surpassed Oman and Yemen to become China's top two oil suppliers in 2003 (Table 3 and Map $1)^{13}$

China and Saudi Arabia established formal diplomatic relations in July 1990. Since 1995, leadership exchanges regarding oil have become frequent. Saudi ministers overseeing the oil sector, finance, or trade visited China each year from 1995-1998 and in 2004. In 1999 the then President Jiang Zemin visited the kingdom and oversaw the signing of a memorandum on petroleum cooperation. ${ }^{14}$ As a result of stronger political ties and economic exchange, Saudi Arabia's share in China's oil imports increased from $2 \%$ in 1995 to $17 \%$ in 2003, topping the list (Table 3).

As Saudi-U.S. ties became strained in the wake of the 9/11 event, Saudi oil shipments to the U.S. declined in 2004. In contrast, Saudi oil exports to China have increased. China-Saudi energy cooperation has deepened. Sinopec has obtained the right to extract natural gas in Saudi Arabia's al-Khali Basin. ${ }^{15}$ In January 2006, King Abdullah bin Abdul-Aziz visited China, signing an agreement on economic cooperation. The kingdom would help China to build a strategic oil stockpile of 100 million tons in Hainan Island and build a new refinery in Guangzhou, involving investment up to US\$8 billion. ${ }^{16}$

Iran is the second largest oil producer in the Middle East. Since the ending of the Iran-Iraq war in 1988 mutual visits by senior leaders (vice president or vice premier and above) of China and Iran have been taking place at least once every other year. The most noticeable ones include Iranian President's visit to China in 1992 and 2000 and a visit by the chairman of China's legislature Qiao Shi in 1996.

The leaders discussed energy and oil cooperation at some of the high-profiled visits. On President Jiang's visit in 2002, both nations also signed a framework agreement on oil and gas cooperation. ${ }^{17}$ In October 2004, China's oil giant Sinopec signed a memorandum of understanding with Iran. The company will buy from Iran 250 million tons of liquefied natural gas over 30 years and develop the Yadavaran field. Iran will export to China 150,000 barrels of crude oil per day for 25 years at market prices after commissioning of the field. ${ }^{18}$

\footnotetext{
${ }^{13}$ Map 1 is based on "An Illustration on China's Petroleum Transport Routes," Zhongguo Guojia Dili (China's National Geography), December 2004, pp. 56-57 and research in this article.

${ }^{14} \mathrm{See}$ various news reports on China-Saudi relations posted at http://www.chinaembassy.org.sa and http://www.fmprc.gov.cn, accessed on October 5, 2004.

${ }_{15}^{15}$ Chietigj Bajpaee, "China Fuels Energy Cold War".

16 "China, Saudi Arabia Extend Energy Ties," posted at Asian Times, January 25, 2006; "Saudi Arabia Signs Important Energy Pact with China,” posted at http://www.peacehall.com/news/ on January 23, 2006 (Source: BBC Chinese).

${ }^{17}$ Zhongguo Waijiao Gailan (A Survey of China's Diplomacy), 1993, pp. 108-109; Zhongguo Waijiao (China's Diplomacy), 2002, p. 109; 2003, p. 174.

18 “China, Iran Sign Biggest Oil and Gas Deal," China Daily, October 31, 2004.
} 
As a result of improved ties, China's oil imports from Iran soared after 1995. China's imports from Iran further grew from 7 million tons in 2000 to 11 million tons in 2002. In 2003 Iran was the second largest oil exporter for China, after Saudi Arabia.

Finally, China and Iran have had military cooperation, drawing awe from Washington. By 2005 the George W. Bush administration had imposed 62 sanctions on Chinese firms for violating controls on the transfer of weapon technology to states, probably including missile technology to Iran. ${ }^{19}$ However, unlike Russia, China is not reported to be engaging in sales of sensitive military technology to Iran. A more important issue is Iran's nuclear program, which will be discussed later.

China also has smooth ties with other West Asian oil producers. China has maintained regular foreign, trade, and petrochemical ministerial visits with Oman and ministerial visits with Yemen, the fourth and fifth largest oil supplier for China, respectively. The President of Yemen visited China in $1998 .^{20}$ China has signed trade and investment agreements with both countries. In September 2004 China and the 15member Arab League jointly promulgated an action plan and made a joint announcement. They have established a biennial forum on politics and economy and have pledged mutual market access and trade and investment cooperation, especially over oil and gas. ${ }^{21}$

\section{Diversifying Imports Sources: Getting Oil from Africa}

China's success in expanding oil imports from the Middle East is not without its problems. Imports from the region accounted for 54\% of China's crude oil imports in 2000 (Table 2). China is concerned about political instability as well as U.S. dominance in the Middle East, especially after the 9/11. In response, it has tried to put its eggs in more than one basket.

China first sets its eyes on Africa, especially Angola, Sudan, Congo, and Gabon. Unlike the Middle East, Africa oil industry is open to foreign investment. Furthermore, the U.S. and EU have distanced itself from these African states due to concerns with human rights violation and violence there. In contrast, China's ties with the region are free of ideological or security obstacles, as well as historical hostilities between the West and these countries.

China established diplomatic ties with Angola in 1983. Their ties have been steady. Since the mid 1990s high-level leadership visits have been frequent. ${ }^{22}$ China assisted Angola with building inexpensive residential housing; it also exempted it all debts due by 1999. ${ }^{23}$ Angola's share in China's oil imports nearly doubled between 1995 and 2003, becoming the third largest external source for China in 2003 (Table 3). In October 2004, China won the purchase of an oil field from Shell in Angola. ${ }^{24}$

\footnotetext{
${ }^{19}$ Chietigj Bajpaee, "China Fuels Energy Cold War"; David Cortright and George A. Lopez, "Bombs, Carrots, and Sticks," posted at http://www.armscontrol.org/act/2005_03/Cortright.asp in March 2005.

${ }^{20}$ Zhongguo Waijiao Gailan, 1993-1995; Zhongguo Waijiao, 1996-2003.

21 "An Action Plan for China-Arab State League Cooperation Forum," and "An Announcement for ChinaArab State League Cooperation Forum," posted at http://www.fmprc.gov.cn, accessed on October 5, 2004.

${ }^{22}$ Zhongguo Waijiao, 1996, pp. 300-01; 1999, pp. 235-236; 2002, p. 215.

${ }^{23}$ Information on Angola posted at http://www.fmprc.gov.cn, accessed on October 2, 2004.

24 "In a Battle over West African Oil Field China Defeats India with 'Heavy Gold," Lianhe Zaobao (United Morning Post), October 16, 2004.
} 
Sudan's relations with Saudi Arabia, its large donor, and Egypt soured between 1989 and 1991. Sudan's ties with the U.S. and the European Union (EU) are also strained by killings of civilians by armed groups and rebels in the country. China thus becomes the much-needed diplomatic life buoy for Sudan. Sudanese President Bashir and the Minister of Energy and Minerals visited China in 1995. Since then at least one very senior official from Sudan has been visiting China every year. In 2000, China's Vice Premier $\mathrm{Wu}$ Bangguo returned a visit and signed a pact for economic and technological cooperation. ${ }^{25}$

Close political ties have helped China's oil giants such as Sinopec and China National Petroleum Corporation (CNPC) to invest heavily in Sudan's oil industry. Bilateral trade, especially in oil, also took off. In 2003, China was Sudan's indisputable top trade partner, accounting for $20-25 \%$ of Sudan's imports and exports. Sudan's share in China's crude imports grew from non-existent in 1997 to a sixth rank in 2003 (Table 3).

China has maintained its ties with Congo through top-level official visits. After the civil war in Congo, China resumes its aid by helping with construction projects and sending medical teams. This aims at rebuilding Congo. Congo's share of China's oil imports increased from nearly zero in 1997 to $4.1 \%$ in 2003 (Table 3).

Finally, China is also forging ties with other African oil producing states. In 2004, on his return trip to France, President Hu Jintao stopped by Gabon, Algeria, and Egypt to discuss deals involving petroleum and natural gas. In the same year, a subsidiary of Sinopec signed an agreement with the French oil corporation Total Gabon to import Gabon's crude oil. ${ }^{26}$

\section{Tapping a Large New Source: Russia}

Even though China succeeds at increasing imports from the Middle East and Africa, it has one concern. Over $75 \%$ of China's oil imports (from the Middle East and Africa) go through the Straits of Malacca (Map 1 and Table 2). As China lacks a blue-water navy, hostile moves by external powers or a severe terrorist attack would acutely disrupt China's oil route.

Since the 2000s, China's oil diplomacy has turned to Russia and Central Asia. It has also explored oil transport routes to bypass the Straits of Malacca. Since 1999 China and Russia have also been edging toward strategic partnership, holding annual bilateral energy cooperation talks under China-Russian regular meeting commission. China's oil imports from Russia have increased sharply in recent years, as the share of Russia in China's crude oil imports soared from $0.2 \%$ in 1995 to a noticeable $5.8 \%$ in 2003. Russia was the seventh largest oil supplier for China in 2003 (Table 3).

China has intensified its diplomatic efforts to increase oil imports through rail and a prospective trans-Siberian oil pipeline. Premier Wen Jiabao visited Moscow in September 2004 and pledged to invest US\$12 billion in Russia's infrastructure and energy sector by 2020. He also declared support for Russia's WTO bid. In return, Wen won on his trip clear pledges from Russia to expand oil exports to China to 10 million

\footnotetext{
${ }^{25}$ Zhongguo Waijiao, 1996, pp. 154-55; 2001, pp. 162-63; information accessed at http://www.fmprc.gov.cn on October 2, 2004.

26 "Hu Jintao Arrives in Gabon to Launch Petroleum Strategy," posted at http://news.bbc.co.uk/chinese and accessed on February 1, 2004.
} 
tons in 2005 and 15 million tons in 2006. China also welcomed very warmly Russian President Putin in Beijing in October 2004, creating a favorable atmosphere for progress in the trans-Siberian pipeline. ${ }^{27}$

China's efforts to obtain the trans-Siberia pipeline, however, are complicated by Japan's competition for a preferred route of the pipeline. In January 2005, Russia, announced the building of the Taisht-Nakhodka pipeline favored by Japan, as well as its start to design a branch to Daqing in China (see Map 1). ${ }^{28}$ These lines may transport 50 and 30 million tons of oil each year, respectively. China would have to pledge to take in 30 million tons a year. ${ }^{29}$ CNPC has allegedly been offered a 20 percent stake in Yukos, the primary Russian oil supplier for China and has given a $\$ 6$ billion loan to the Russian oil giant Rosneft for purchasing Yugansk, Yukos's key unit. ${ }^{30}$

\section{Forging Cooperation with Central Asia}

Central Asia, or the region around the Caspian Sea which is now part of the CIS (Confederation of Independent States), is another new source of oil supply for China. In that region Kazakhstan has the greatest potential for supplying oil to China. Energy cooperation between the two countries was officially launched in 1997, when Vice Premier Li Lanqing signed an agreement on energy cooperation on his re-visit to Kazakhstan. ${ }^{31}$

There have been three important deals between the two countries. One is an agreement by the two governments in 1997 to invest $\$ 2.5-3$ billion in building a 3088-km pipeline from Atyrau in western Kazakhstan to Dushangzhi in Xinjiang (see Map 1). The section from Qandyaghash to Atasu was complete in March 2003. ${ }^{32}$ Construction of the section of the pipeline from Atasu in Kazakhstan to Alashankou in China's started in September 2004. When completed, the pipeline would double Kazakhstan's oil exporting capacity to 20 million tons a year. ${ }^{33}$ The other is the CNPC's acquisition of a $60 \%$ stake in the Kazakh oil company Aktobemunaigaz in 1997 and its pledge to invest a large sum in the latter over 20 years. ${ }^{34}$ The third is the takeover of PetroKazakhstan by the CNPC, China's state-owned oil giant, in August 2005 at a price of $\$ 4.18$ billion. PetroKazakhstan is a Canadian oil company with substantial reserves in Kazakhstan and an annual production capacity of 7 million tons. ${ }^{35}$

\footnotetext{
27 "Premiers of China and Russia Settled for Goals in Oil and Gas Cooperation," posted at http://wwwmlr. gov.cn and accessed on September 27, 2004..

28 "Russian Oil Pipeline to Japan Will Branch Out to China," Agence France Presse, January 28, 2005.

29 "At a Cost, Siberia Pipeline to Send Oil to Pacific," International Herald Tribune, January 22-23, 2005, p. 1; "Russian Angarsk -Nakhodka Pipeline Plan Will Complete Next Year-A Subsidiary Line to Daqing Will Be Included," posted at http://www.chinanews.com.cn and accessed on November 27, 2003.

${ }^{30}$ Chietigj Bajpaee, "China Fuels Energy Cold War," Asian Times, March 2, 2005.

${ }^{31}$ Information posted at http://www.fmprc.gov.cn on August 21, 2003, and accessed on October 2, 2004.

32 "Background Materials: China-Kazakh Oil Pipeline," posted at http://www.XINHUANET.com on September 28, 2004.

33 "Construction of the China-Kazakh Oil Pipeline Started Today and Xinjiang Would Become China's Oil Warehouse," posted at http://www. XINHUANET. com on September 28, 2004.

${ }^{34}$ Information posted at http://www.eia.doe.gov, accessed on October 2, 2004.

35 “CNPC Takes Over PetroKazakhstan with \$4.18 Billion,” posted at http://www.XINHUANET.com on August 23, 2005.
} 
In September 2004 China also signed a compendium with Kyrgyzstan. It covered cooperation priorities and programs for the next decade, including cooperation in communications and energy. ${ }^{36}$

\section{Extracting Latin and North American Oil}

In recent years China has stepped up its oil cooperation with Latin America. China signed five energy agreements with Venezuela, South America's largest oil producer and the world's fifth-largest oil exporter. CNPC will set up a joint venture with its Venezuelan counterpart Petroleos de Venezuela to develop 14 oil fields in the Zumano area, which hold reserves of 400 million barrels of oil and three billion cubic feet of natural gas. The Chinese investment may amount to US $\$ 4$ billion. ${ }^{37}$ China may import oil from Venezuela through ports on the Pacific in Colombia. China's oil enterprises are investing and taking up projects in oil exploration in Ecuador. China was expected in 2004 to become the third-leading destination of Brazilian crude oil exports, with shipments of about 50,000 barrels per day. ${ }^{38}$

In 2003, Chinese state-owned enterprises (SOEs) invested $\$ 1.04$ billion in Latin America, accounting for $36.5 \%$ of foreign direct investment (FDI) in the region. Much of the investment was made in mines, energy exploration, and infrastructure. In November 2004, on his visit to Chile, Brazil, Argentina, and Cuba President Hu pledged to pump $\$ 100$ billion in the region in the coming decade. ${ }^{39}$

In January 2005, China and Canada signed a joint statement on energy cooperation during Canadian Prime Minister Paul Martin's visit to China. It announced that China would extract Canada's oil sands and uranium resources. ${ }^{40}$

\section{Sustaining Imports of Oil Products}

In addition to crude oil, China also imports oil products, including gasoline, diesel oil, kerosene, and fuel. Its total imports, however, go through cyclical change, declining from 23.8 million tons in 1997 , to 18.1 million tons in 2000 , and recovering to 20.3 million tons in 2002. South Korea, Singapore, and Russia were primary exporters, each accounting for at least 14\% of China's imports from 1997-2002. They are followed by Japan, Malaysia, and the Philippines. ${ }^{41}$ As China's oil imports were not transported via the Straits of Malacca, China may feel slightly relieved. China is also investing in refinery overseas. In September 2004, Sinochem completed China's first takeover of a foreign oil company, that is, Inchon Oil, a South Korean small refiner, for about US\$549 million. $^{42}$

\footnotetext{
36 “China, Kyrgyzstan Tap Co-operation Potential,” China Daily, September 23, 2004.

37 "Oil Accords Signed with Venezuela," The Standard, January 31, 2005.

38 “Transformation of China's Overseas Oil Search,” Guoji Xianqu Daobao (International Herald Leader), December 31, 2004, p. 4.

${ }^{39}$ Willy Lam, "China's Encroachment On America's Backyard," China Brief, Volume 4, Issue 23 (November 24, 2004), Washington, D.C.: Jamestown Foundation.

40 "In Search of Crude China Goes to the Americas," posted at http://www.iags.org/n0118041.htm on January 19, 2006.

${ }^{41}$ See Yearbook of China's Economic Foreign Relations and Trade 1998, 2002, 2003.

42 "Sinochem Signs Deal to Buy Ailing Refiner Inchon," The Standard, September 25, 2004.
} 


\section{Considering Alternative Routes in South and Southeast Asia}

Currently over $75 \%$ of China's crude oil imports have to go through the $1100-\mathrm{km}$-long Straits of Malacca (see Map 1). Naturally, China's second major initiative in oil diplomacy is to avoid possible disruption to the route by the U.S., Japan, India, as well as terrorist attacks. China is allegedly following the so-called "string of pearls" strategy -building close ties along the sea lanes from the Middle East to the South China Sea in order to protect China's energy interests and sea lanes. These "pearls" include Pakistan, Bangladesh, Myanmar, Thailand, Cambodia, and the South China Sea. ${ }^{43}$ More importantly, China is considering an alternative oil transport route in South and Southeast Asia in case of emergencies. Four alternatives have emerged, as detailed in Map 1.

The first and the safest for China is the transport line from the Port of Gwadar in Pakistan located near the mouth of the Strait of Hormuz through pipeline into Xinjiang. In 2001 China agreed to build a deep-sea port there, with total estimated costs of $\$ 1.16$ billion. Backed by strong ties with Pakistan, China can exercise considerable influence over the port. China can transport oil from the Middle East (such as Oman) to Xinjiang bypassing the Persian Gulf, the Indian Ocean, the Straits of Malacca, and the South China Sea. The main obstacle is the severely cold weather in Xinjiang which may pose hazards for the pipeline; there is also the possibility of sabotage by Baloch nationalists in Pakistan. $^{44}$

The second alternative to the Straits of Malacca is a $1700-\mathrm{km}$ pipeline connecting Kunming in China to the deep-water port of Sittwa in western Myanmar, at an estimated cost of US\$2 billion. Along this route is the critical 900-km segment connecting Ruili of China with Mandalay. ${ }^{45}$ In a likely effort to buttress the pipeline plan, CNOOC, China's largest offshore oil producer, as well as Sinopec, attained permission in 2004 to explore two blocks, respectively in Rakhine and Rangoon of Myanmar. ${ }^{46}$

The third is the rail across the mainland Southeast Asian, running from southwest China to Singapore or Myanmar. Three routes of the railway have been proposedeastern, central, and western. The eastern route seems the most promising at present as it involves minimum construction. The fourth alternative to the Straits of Malacca is a route across the Kra Isthmus. Original proposals involve a canal. ${ }^{47}$ In June 2004, Thailand state energy company PTT and Sinopec announced a joint project to explore a pipeline north to Phuket with a capacity of 1.5 million barrels a day. ${ }^{48}$

\footnotetext{
${ }^{43}$ Booz Allen Hamilton's report entitled "Energy Futures in Asia" for the Pentagon, cited in Sudha Ramachandran, "China's Pearl in Pakistan's Waters," Asia Times, March 4, 2005.

44 "Do Not Ask Where the Oil Comes From, As Long As the Oil Route Is Under Control," Guoji Xianqu Daobao (International Herald Leader), December 31, 2004, p. 4.

45 “Searching for Tomorrow's Petroleum," Zhongguo Guojia Dili (China's National Geography), December 2004, pp. 66-67.

46 “China Eyes Burma Oil Deal," The Standard, October 26, 2004.

47 "Searching for Tomorrow's Petroleum,” pp. 62-63.

48 "China Mulls Oil Pipelines in Myanmar, Thailand," Asian Times, October 1, 2004.
} 


\section{Implications for the U.S., Asia and Other Countries}

Understandably, China's oil diplomacy and quest for overseas crude affect its relations with three types of nations differently. First, China will strengthen its relations with oil producing and exporting nations. Second, China may both compete and cooperate with nations that moderately rely on imported crude, including the U.S., India, and a number of Southeast Asian nations. Third, China may compete fiercely with nations that heavily rely on imported oil, especially Japan. Nevertheless, these effects depend also largely on the state of China's relations with these nations, the extent of China's reliance on imported oil, as well as the efforts by China and nations concerned to contain conflict. In this section effects of China's oil diplomacy will be discussed. Here predictions about a China aggrandizing on the U.S. vital interests will be compared with the actual development. Many of these predictions turn out to be fictions.

\section{China's Closer Bonds with Oil Producing States}

As detailed in the above analyses China has striven to expand its overseas oil supplies. Naturally, China will strengthen its ties with oil producing nations that are willing to cooperate with China, or whose oil supplies are still available for tapping. These nations include Saudi Arabia, Iran, Omen, and Yemen in the Middle East, Angola, Sudan and Gabon in Africa, Russia and Kazakhstan among the former Soviet republics, Venezuela and Brazil in Latin America, and Canada. Understandably, China may sympathize with these nations over issues deemed vital by these nations, if this requires China's limited efforts and implies little or limited harms for China's interests. Several examples are illustrating. First, the Middle East and the Palestine-Israeli conflict. Partly out of its need to sustain oil supplies from the Middle East, China sympathizes with Arab's world stance on Palestine. At the request of Saudi Arabia, China called on all parties in 2003 to stop the vicious cycle of violence against violence and tackle outstanding issues in the Israeli relations with Palestine, Lebanon, and Syria on the principle of land for peace; it also supported a nuclear-free Middle East. China has also forged multilateral ties with the Arab world. In September 2004 the China-Arab League biennial forum on politics and economy affirmed China's 2003 stance on the Middle East. ${ }^{49}$

Second, Sudan. China provides valuable diplomatic support for Sudan, its second largest African oil supplier over sensitive issues. China moderates the Western pressure for imposing sanctions against Sudan for growing atrocities in Darfur, Sudan. The Chinese subtle support brought Sudanese much relief. ${ }^{50}$

\section{China's Accommodation to and Minor Frictions with the U.S.}

It has been tempting, given the above analysis, that China, out of its own need to get oil from these nations, will undermine the U.S. oil security or contravene U.S. policies toward these oil producing nations. The most noticeable areas that critics and pessimists

\footnotetext{
49 "An Action Plan for China-Arab State League Cooperation Forum," and "An Announcement for ChinaArab State League Cooperation Forum," posted at http://www.fmprc.gov.cn, accessed on October 5, 2004.

${ }^{50}$ See “U.N. Puts Sudan Sanctions into Play," Washington Post, September 19, 2004, Page A01; "China May Convince U.S. Not to Sanction Sudan,” accessed at http://www.smcsudan.net on October 14, 2004.
} 
have suggested include Iraq, Iran, Sudan, sea lanes, and the U.S. oil security. However, China's stances in these cases have so far indicated that these fears have been far exaggerated.

First, Iraq. Prior to the U.S. invasion of Iraq, many believed that China, in order to secure oil from the region and show its sympathy to Saddam Hussein, might have blocked the U.S. related initiatives over Iraq at the U.N. However, China actually voted in favor of the U.N. Security Council Resolution 1441 in 2002 that held Iraq in 'material breach' of disarmament obligations, which opened the way for the U.S.-led war against Saddam Hussein.

Second, Iran. In 2004 and 2005 when Iran-U.S. tension was escalating over Iran's nuclear program, many observers predicted that China would fully back Iran in the crisis and oppose the U.S. efforts to refer the issue to the U.N. A comment summed up a popular sentiment about a China-Iran oil deal in 2004 as follows: "For a United States increasingly pointing at China as the next biggest challenge to Pax Americana, the IranChina energy cooperation cannot but be interpreted as an ominous sign of emerging new trends in an area considered vital to US national interests." 51 However, in early 2006 China backed a proposal initiated by the U.S. and Europe to refer Iran's nuclear program to the U.N. Security Council should Iran fail to cooperate. China also agreed with the principle that Iran should not develop nuclear weapons. ${ }^{52}$

Third, Sudan. In September 2004, the U.N. Security Council was deliberating a resolution which threatened to halt Sudan's oil exports if it did not stop the atrocities by pro-government militias in the Darfur region that led to the deaths of tens of thousands due to starvation or illness. In this case China distanced itself from the stance led by the EU that used sanctions to force Sudan to take action. However, China was not alone. Russia, Pakistan and Algeria abstained from voting on the resolution. China did try to find a compromise by talking the U.S. into watering down the U.N. resolution before allowing it to pass, instead of vetoing it. Many observers attributed the Chinese action to the fact that China obtained 6.9 percent of its oil imports from the African country. A stronger reason, however, might be China's $\$ 3$ billion investment in the country, the largest China made in any single country at that time. ${ }^{53}$ China's position on Darfur raises concerns of advocates for human rights. The Darfur issue is actually complex. Darfur is a battlefield where rebels fight Sudanese troops, aiming to topple the government. Fighting, lawlessness, and poorly paid and equipped and corrupt police permit crimes to proliferate. A practical solution, which the U.S. and the U.N. are pushing forth, is to send in peace-keeping troops to enforce ceasefire as well as law and order. China seems open to the solution. 54

Fourth, the security of sea lanes. It has been feared that China would rapidly develop its capability to safeguard its sea lanes from Persian Gulf through the Straits of Malacca and the South China Sea to China and that it may disrupt the U.S. and Japan sea

\footnotetext{
${ }^{51}$ Kavah L. Afrasiabi, "China Rocks the Geopolitical Boat with Iran Oil," Asia Times, November 6, 2004.

52 "China and Russia Support Sending Iran Case to U.N.," New York Times, January 31, 2006.

${ }^{53}$ Colum Lynch, "U.N. Puts Sudan Sanctions Into Play: Security Council Adopts Resolution,"

Washington Post, September 19, 2004, p. A01; "China's Oil Ties to Sudan Force It to Oppose Sanctions,"

Sudan Tribune, 20 October 2004.

${ }^{54}$ For the situation of Darfur, refer to "Policing the Police in the Chaos of Darfur," New York Times,

February 5, 2006; "Larger Darfur Force Needed, Bush, Annan Say," Washington Post, February 14, 2006, A12.
} 
lanes in the case of war. Actually, so far China's naval capability mainly covers the Taiwan Strait and copes with Taiwan's possibly provocative declaration of independence. Its blue-water navy is still a concept than a reality. Its abilities to safeguard and/or disrupt sea lanes from the Persian Gulf to the South China Sea have been rather limited. China's any disruption of sea lanes would invite strong counter-moves by the other parties and could be highly counterproductive. Therefore, China's most efforts at securing its oil routes have been to find alternative land pipelines or railways. China also apparently falls back on the U.S. protection to ensure safety of its sea lanes for oil. ${ }^{55}$

Fifth, the U.S. oil security. Intensified concern in media with Chin's oil diplomacy leaves an impression that China's quest for oil the Middle East would reduce oil available for the U.S. and undermine the U.S. oil security. ${ }^{56}$ This worry is not based on facts. The U.S. imports from Arab OPEC nations (presumably the Middle East) only accounted for $14.8 \%$ of its oil consumption in 2005. The top two importing sources for the U.S. are Canada and Mexico. The U.S. annual oil consumption in 2004 amounted to 1,011.6 million tons and its imports 590.3 million tons. ${ }^{57}$ China's oil imports from the Middle East totaled 51.7 million tons, taking up 51.3\% of its oil imports in 2003. However, it accounted for $20.5 \%$ of its oil consumption and only $4.7 \%$ of its total energy consumption. ${ }^{58}$ It was equivalent to $8.8 \%$ of the U.S. total imports and $5.1 \%$ of its oil consumption. China's imports are thus not large enough to upset U.S. oil imports.

\section{China's Competition for Oil in Asia}

Asia is the fast-growing oil market in the world. China's rising demands for oil inevitably places itself in competition with other major Asian oil consumers. The first one is India, whose demands for oil are also growing due to its surging economy. In October 2004, China beat India's biggest oil company, state-owned Oil \& Natural Gas Corp (ONGC) in winning the purchase of an oil field from Shell in Angola. ${ }^{59}$ In 2005, China again edged over India in an effort to take over PetroKazakhstan, a Canadian oilproducer in Kazakhstan. ${ }^{60}$ In January 2006, Chinese state-controlled oil company CNOOC outlasted India's ONGC in winning a 45 percent stake in a Nigerian oil field at a price of $\$ 2.3$ billion. $^{61}$

China is also competing for oil with other countries, chiefly Japan. China and Japan have betted against each other to win their favorite route of Russia's trans-Siberia pipeline. They are also entering a heated dispute over China's extraction of gas in the sea between them. Even though China and Japan have held rounds of talks over joint exploration in the East China Sea, no agreement has been reached.

\footnotetext{
${ }^{55}$ Downs, China's Quest for Energy Security, p. xii.

${ }^{56}$ One comment, for example, runs as follows: "History shows the opposite: Superpowers find it difficult to coexist while competing over scarce resources." See Gal Luft, "U.S., China Are on Collision Course Over Oil," Los Angeles Times, February 2, 2004.

57 These data are based on statistics provided at http://www.eia.doe.gov/neic/quickfacts/quickoil.html.

${ }^{58}$ See Tables 1 and 2 and China Statistical Yearbook, 2005, p. 255.

59 "In a Battle over West African Oil Field China Defeats India with 'Heavy Gold"'.

60 "India Is Casting a Wide Net in Its Hunt for Energy," International Herald Tribune, January 24, 2005 , p. 12.

61 “India, China to Sign Pact on Cooperation," Washington Post, January 10, 2006.
} 


\section{China's Cooperation with India and Southeast Asia}

Nevertheless, into the 2000s China has also made noticeable progress in oil and gas cooperation with Southeast Asian and South Asian nations. Therefore, the worst-case scenario about clashes over oil between China and other claimant states in the South China Sea, or between China and India, and even between China and Japan have not happened.

The South China Sea has deposits of oil and gas. The U.S. Geological Survey and others estimate that about $60 \%-70 \%$ of the region's hydrocarbon resources are gas. South China Sea has proven oil reserves estimated at about 7.0 billion barrels. Oil production in the region is around 2.5 million barrels per day and has increased gradually over the past few years, as China, Malaysia and Vietnam step up production. China and Southeast Asian nations have overlapping claims over the Spratly and Paracel Islands in the South China Sea. Nevertheless, these nations have worked out a temporal solution. In November 2002, China and ten ASEAN members signed a Joint Declaration on the Conduct of the Parties, pledging to "resolve their territorial and jurisdictional disputes by peaceful means". ${ }^{62}$ In March 2005, three oil companies from China, Vietnam and the Philippines signed a landmark tripartite agreement in Manila on joint exploration of oil and gas resources in the disputed South China Sea. The three parties stated their willingness to prospect the reserve of petroleum resources within the area agreed by them, without undermining the basic positions held by their own governments. ${ }^{63}$

China has also furthered its cooperation with Indonesia in gas exploration and trade. In September 2002, China awarded a US\$8.5 billion liquefied natural gas (LNG) purchase contract to Indonesia. ${ }^{64}$ In 2002, with a purchase of a field from the Spanish firm Repsol YPF SA, CNOOC, became the largest offshore oil producer in Indonesia. ${ }^{65}$

Despite competing at times for controls of oil fields overseas, China and India have also expressed a strong desire to cooperate and have taken steps. China and India have already been working together in extracting oil in Iran. At the beginning of 2005, India sealed a $\$ 40$ billion deal with Iran to import 7.5 million tons of liquefied natural gas annually over the coming 25 years. India also acquired stakes in the development of Iran's largest onshore oilfield, Yadavaran and the Jufeir oilfield. The Yahavaran oilfield has become a Sino-Indian-Iranian joint project, with India holding a $20 \%$ stake, China $50 \%$ and Iran $30 \%{ }^{66}$

In December 2005, CNPC and India's ONGC jointly bid for petro-Canada's interest in Al Furat Petroleum, a joint venture with Syrian Petroleum and Syria Shell Petroleum Development. ${ }^{67}$ In January 2006, India and China, signed a "Memorandum for Enhancing Cooperation in the Field of Oil and Natural Gas", pledging to jointly bid

\footnotetext{
62 "South China Sea Region," accessed at http://www.eia.doe.gov/emeu on January 3, 2006.

63 "China, Vietnam Agree to Promote South China Sea Joint Exploitation," posted at http://english.people.com.cn/ (People's Daily Online), on July 20, 2005.

64 "China also Engages in Energy Trade with Southeast Asia," People's Daily, September 27, 2002.

65 "With Iraq Deal Dissolved by War, Beijing Looks Elsewhere," Washington Post, July 13, 2005, D01.

${ }^{66}$ Chietigj Bajpaee, "India, China Locked in Energy Game," Asia Times, March 17, 2005.

67 "India Is Casting a Wide Net in Its Hunt for Energy," International Herald Tribune, January 24, p. 12.
} 
for energy projects. It also encouraged cooperation in energy exploration, production, storage and stockpiling, research and development and conservation. China and India hope that cooperation will help bring down prices in Asia. India is also open to a pipeline project connecting India and China. ${ }^{68}$

Since January 2004, China's ally Pakistan, under China's persuasion, has improved ties with India, its long-time arch rival. This development, coupled with higher oil price, has raised the interests from two countries for the Iran-Pakistan-India "peace pipeline". Pakistan has pledged that it will not switch off gas flow, even amidst Indo-Pak tensions or hostilities. ${ }^{69}$

Even though China contests fiercely with Japan over Russian oil in Siberia and over gas exploration in the East China Sea, both countries have also embarked upon cooperation over oil. It is not uncommon for large oil companies of two countries to work together to materialize trade deals. Reportedly, the Ministry of Economy, Trade and Industry has formed an energy group on China, devoting to supplying China technology for oil stockpiling. The Japanese Government also expresses its willingness to assist Asian nations, China presumably included, with utilizing non-oil energy such as wind and solar power suitable for their own geography. ${ }^{70}$

\section{China's Limited Imports Dependence and "Peaceful Rise"}

Two reasons help to account for China's peaceful oil diplomacy. First, China's dependence on imported oil for meeting its consumption need is still limited. In 2004, over two-thirds (67.7\% to be exact) of China's energy consumption came from coal, $22.7 \%$ from oil, $7 \%$ hydro-power, and $2.6 \%$ natural gas. In that year $40 \%$ of China's oil had to be imported in 2004, accounting for only $9.1 \%$ of China's energy consumption. ${ }^{71}$ Therefore, imported oil plays only a minor role in China's energy consumption. Domestically produced coal plays a crucial role and domestically produced oil and hydropower a secondary role. Large oil producing nations merely provided a small fraction of China's energy consumption. Iran, for example, supplied merely $1 \%$ of China's energy consumption in 2003. Much of the fear and suspicion about China's aggressive and destabilizing oil diplomacy has thus not been based on a realistic appreciation of China's domestically-based energy source.

Even though China's oil dependence is posed to increase, China has taken measures to curb this trend. In late 2005 China's top economic officials stated that China would develop renewable energy to minimize dependence on oil and oil imports. ${ }^{72}$ For this purpose China will also make alternative energy sources a guideline as its energy policy in the Eleventh Five-year Plan covering 2006-2010. ${ }^{73}$ This policy has apparently started to reduce China's reliance on oil and oil imports. According to China's National

\footnotetext{
68 "India, China to Sign Pact on Cooperation," Washington Post, January 10, 2006.

${ }^{69}$ Chietigj Bajpaee, "India, China Locked in Energy Game".

70 "Japan Has a Good Solution to the Oil Issue," Lianhe Zaobao (United Morning Post), October 15, 2004.

${ }^{71}$ See Tables 1 and 2 and China Statistical Yearbook, 2005, p. 255.

72 "As Energy Becomes Top Concerns, Leaders Push Forth Changes in China's Energy Policy," posted at and accessed at http://www.phoenixtv.com/phoenixtv on September 28, 2005.

73 "Dependence on Oil Needs to Be Cut, Says Panel," China Daily, February 13, 2006.
} 
Development and Reform Commission (NDRC), China's dependence on oil imports in 2005 was 42.9 per cent, 2.2 percentage lower than in 2004; China consumed 318 million tons of oil in 2005, 1.08 million tons less than in $2004 .^{74}$

Second, China's leadership has been taking great care to ease external fear about its economic and political rise. Under President Jiang Zemin China strove to portray itself as "a responsible great power" that enhanced peace, prosperity and stability in the world. Under the current President $\mathrm{Hu}$ Jintao, China proclaimed that it will follow the course of peaceful rise. China later rephrased it as peaceful development in order to assay the world sensitive concerns with a rising China. Thus the Chinese leadership is aware and sensitive to international reaction to China's oil diplomacy and tries to minimize negative repercussions. China's eventual acquiescence to the U.S. stance over Iraq and Iran and its compromise with the U.S. over Sudan's human dislocation illustrate China's pragmatic and low-key approach in securing imported oil and managing issues of vital concerns to the U.S. In addition, China has also displayed considerable interests and enthusiasm for peaceful resolution of conflict and for constructive cooperation over oil with its Asian neighbors. China's cooperation with India in joint oil development and with claimant states in the South China Sea offers the best albeit very surprising examples.

\section{Conclusion}

This article sets out to review and assess China's oil diplomacy in the recent years. Since the 1990s, China's demand for imported oil has increased. In response, China has launched a number of external initiatives to secure overseas oil supplies. First, China has strengthened its ties with oil producing nations in the Middle East, Africa, Central Asia, Latin and North Americas. China's state oil companies also actively seek to invest in overseas energy ventures. Second, China is developing alternate oil land routes to reduce its reliance on the Straits of Malacca. Apparently, China does not have the capacity to prevent the U.S. from disrupting its sea lanes. Developing land routes for oil transport appears to be China's best option.

Many pessimistic arguments about China's conflict-prone oil diplomacy are invalidated by actual developments. In particular, over Iraq, Iran, the South China Sea, and the U.S. oil security, China has not proved to be highly detrimental. China has not scuttled the U.S. diplomatic efforts for its war in Iraq and for applying pressure on Iran over its nuclear program at the U.N. China's oil imports are not large enough to disrupt U.S. oil supplies. Even though China objected to sanctions on Sudan, China did reach a compromise with the U.S. in passing the U.N. resolution pressuring Sudan to stop ethnic killings as well as starvation and illness. ${ }^{75}$

While China's quest for overseas oil intensifies its competition with other Asian oil consuming nations, China has joined hand with India and Indonesia over oil exploration.

\footnotetext{
${ }^{74}$ See "China's Oil Consumption, Imports Decreased," China Daily, February 3, 2006. The statistics from the NDRC apparently differ slightly from those in Table 1 in this article that base on BP and customs data.

${ }^{75}$ One recent study portrays China's strategy regarding the U.S. as accommodating to and hedging the U.S. unipolar world, instead of opposing it. See Rosemary Foot, "Chinese Strategies in a US-Hegemonic Global Order: Accommodating and Hedging," International Affairs, 2006: Vol. 82, No. 1, pp. 77-94.
} 
Rather than fighting a war over the disputed South China Sea, China has reached an agreement on joint energy exploration with Vietnam and the Philippines. The predicted oil war in Asia, especially in the South China Sea has been a fiction rather than a reality.

While China's oil diplomacy has not been a threat to the world, there are also trouble spots. The main flashpoint has been China-Japan disputes over the East China Sea. China and Japan have overlapping claims over territorial water, islets (Diaoyutai or Senkaku Islands being the most prominent) and reefs in that area. Several rounds of their talks on joint exploration have not resulted in an agreement, and the disputed territorial water amounted to 300,000 square kilometers. Obviously, their dispute does not stand all by itself. It has been fueled much by their dispute over history, especially Japanese Prime Minister Koizumi's controversial visit to the Yasukuni Shrine. There are also encouraging signs. In October 2006 Japanese new Prime Minister Abe visited Beijing. Leaders of Japan and China met in one's capital for the first time since 2001. Both nations agree to joint exploration in principle and have been negotiating. Both also feel that armed clashes in that area would be destructive. The gateway for peaceful resolution has not been closed. 
Table 1. China's Production, Consumption and Imports of Crude Oil (million tons)

\begin{tabular}{|c|c|c|c|c|c|}
\hline Year & Production & Consumption & Imports & Exports & Self-sufficiency Ratio (\%) \\
\hline 1980 & 106.0 & 87.6 & 0.4 & 13.3 & 113.9 \\
\hline 1985 & 124.9 & 91.7 & 0.7 & 31.2 & 132.3 \\
\hline 1990 & 138.3 & 114.9 & 2.8 & 24.9 & 119.0 \\
\hline 1995 & 149.0 & 160.7 & 17.1 & 18.8 & 101.2 \\
\hline 2000 & 162.6 & 230.1 & 70.3 & 10.3 & 73.0 \\
\hline 2001 & 164.8 & 232.2 & 60.3 & 7.6 & 75.8 \\
\hline 2002 & 168.9 & 245.7 & 69.4 & 7.2 & 73.1 \\
\hline 2003 & 169.3 & 252 & 91.0 & 8.1 & 67.1 \\
\hline 2004 & 175.5 & 292.7 & 122.7 & 5.5 & 60.0 \\
\hline
\end{tabular}

Sources: China Statistical Yearbook, 2003; 2005; Yearbook of China's Economic Foreign Relations and Trade 2003; British Petroleum Statistical Review of World Energy, June 2003;

"China's Crude Imports Exceeded the Threshold of 100 Million Tons," posted at http://www.XINHUANET.com on January 25, 2005.

Table 2. China's Regional Sources of Imported Crude Oil, 1995-2003 (\%)

$\begin{array}{lccc}\text { Regions } & 1995 & 2000 & 2003 \\ \text { Middle East } & 45.4 & 53.6 & 51.3 \\ \text { Africa } & 10.8 & 24.0 & 24.4 \\ \text { Asia-Pacific } & 42.3 & 15.0 & 15.3 \\ \text { CIS (Russia \& Kazakhstan) } & 0.2 & 3.1 & 7.2 \\ \text { Europe } & 2.1 & 3.6 & 1.8 \\ \text { South America } & 0 & 0 & 0.4\end{array}$

Sources: Yearbook of China's Economic Foreign Relations and Trade 2002, 2003; Feeidun Fesharaki, "Energy Security in Asia Pacific," public lecture at Institute of Southeast Asian Studies, Singapore, June 8, 2004. 
Table 3. Primary Sources of Crude Oil Imports for China, 1995-2003 (\%)

$\begin{array}{ccccc}\text { Country } & 1995 & 2000 & 2003 & \text { Rank, 2003 } \\ \text { Saudi Arabia } & 2 & 8.2 & 16.8 & 1 \\ \text { Iran } & 5.4 & 10.0 & 13.8 & 2 \\ \text { Oman } & 21.4 & 22.3 & 10.3 & 4 \\ \text { Angola } & 5.9 & 12.3 & 11.2 & 3 \\ \text { Yemen } & 14.5 & 5.1 & 7.8 & 5 \\ \text { Sudan } & 0 & 4.7 & 6.9 & 6 \\ \text { Congo } & 0.1 & 2.1 & 4.1 & 8 \\ \text { Russia } & 0.2 & 2.1 & 5.8 & 7 \\ \text { Kazakhstan } & 0 & 1.0 & 1.3 & 14 \\ \text { Vietnam } & 4.4 & 4.5 & 3.9 & 9 \\ \text { Indonesia } & 30.9 & 6.5 & 3.7 & 10 \\ \text { Malaysia } & 3.5 & 1.1 & 2.2 & 11 \\ \text { Australia } & 0.4 & 1.6 & 2.0 & 12 \\ \text { Brunei } & 0 & 0.4 & 1.7 & 13 \\ \text { Norway } & 0 & 2.1 & 1.1 & 15\end{array}$

Notes: Countries in bold have dramatic increase in share of China's oil imports; countries which are underlined are countries which have significant drop in shares.

Sources: Yearbook of China's Economic Foreign Relations and Trade 1996/97, 1998, 2002, 2003. 
Map 1: China's Current and Prospective Oil Routes

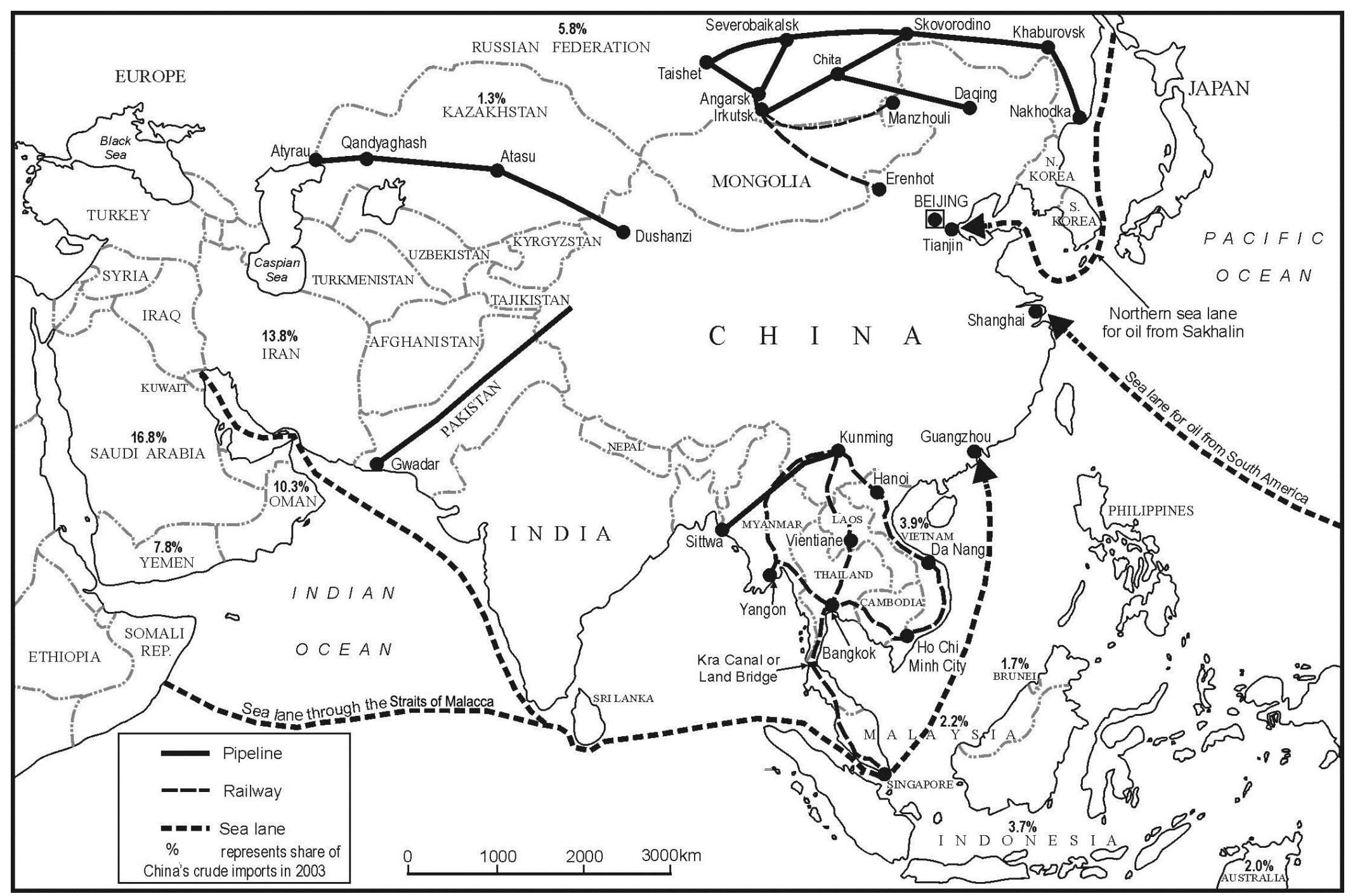

